January 2003

\title{
Extractable Soil Phosphorus Concentrations and Creeping Bentgrass Response on Sand Greens
}

Karl Guillard

University of Connecticut Department of Plant Science, karl.guillard@uconn.edu

William M. Dest

Follow this and additional works at: https://opencommons.uconn.edu/plsc_articles

\section{Recommended Citation}

Guillard, Karl and Dest, William M., "Extractable Soil Phosphorus Concentrations and Creeping Bentgrass Response on Sand Greens" (2003). Plant Science Articles. 4.

https://opencommons.uconn.edu/plsc_articles/4 


\title{
Extractable Soil Phosphorus Concentrations and Creeping Bentgrass Response on Sand Greens
}

\author{
Karl Guillard* and William M. Dest
}

\begin{abstract}
Few studies have directly related turfgrass growth and quality responses to extractable soil $P$ concentrations in sand greens. A 3-yr field experiment was conducted on a sand-based putting green to determine creeping bentgrass (Agrostis stolonifera $\mathbf{L}$.) growth and quality responses to extractable soil $P$. Extractable soil $P$ concentrations were obtained by using the modified-Morgan, Mehlich-1, and Bray-1 extractants. Critical extractable $P$ concentrations (above which there is a low probability of response to increasing soil $P$ concentrations) for shoot counts, thatch thickness, relative clipping yields, quality ratings, $P$ deficiency ratings, tissue $P$ concentrations, and root weights were determined using Cate-Nelson $(\mathrm{CN})$ and quadratic response and plateau (QRP) models. Both models fit the data relatively well in most cases ( $R^{2}$ values from 0.12 to 0.89$)$, and critical concentrations for the QRP models were always greater than the $\mathrm{CN}$ models. Critical extractable $P$ concentrations were lowest for the modifiedMorgan extractant (1.4 to $12.0 \mathrm{mg} \mathrm{kg}^{-1}$ ) and greatest for the Mehlich-1 extractant (14.1 to $63.6 \mathrm{mg} \mathrm{kg}^{-1}$ ). Application of estimated critical extractable $P$ concentrations in this study could be used to substantiate observed responses or explain lack of responses in other previously reported creeping bentgrass $P$ studies. We found better model fits with modified-Morgan extractable $\mathbf{P}$ for bentgrass quality ratings, deficiency ratings, and tissue $P$ concentrations than with $P$ extracted by the Mehlich or Bray methods. This suggests that the modifiedMorgan extractant may have advantages over stronger-acid extractants when used on sand-based media. The results can be used to revise or update existing $P$ fertilization recommendations for bentgrass grown on sand-based media.
\end{abstract}

$\mathrm{C}$ REEPING BENTGRASS (Agrostis stolonifera L.) is a cool-season turfgrass used extensively for golf putting greens. Phosphorus management for creeping bentgrass greens is not well-defined. Many greens may be low in extractable soil $\mathrm{P}$ concentrations because of the intentional withholding of $\mathrm{P}$ fertilizers. Application of $\mathrm{P}$ has been shown to increase annual bluegrass ( $\mathrm{Poa}$ апnиа L.) populations and growth (Goss et al., 1975; Waddington et al., 1978; Dest and Allinson, 1981; Lodge et al., 1990; Kuo et al., 1992; Kuo, 1993b). Therefore, P fertilization is frequently reduced on creeping bentgrass greens as a means of controlling annual bluegrass. Low extractable soil $\mathrm{P}$ concentrations are also a result of the increased use of sand-based rootzone mixes for putting green construction. Most of these sands are inherently infertile, and unless fertilized, they are unable to supply the amount of $\mathrm{P}$ needed for sufficient creeping bentgrass growth and quality. Colclough and Lawson (1989) reported that $\mathrm{P}$ deficiency ratings of Festuca-Agrostis sand

Dep. of Plant Science, Univ. of Connecticut, 1376 Storrs Road, Unit4067, Storrs, CT 06269-4067. Scientific Contribution no. 1969 of the Storrs Agric. Exp. Stn., Storrs, CT. Received 27 Aug. 2001. *Corresponding author (karl.guillard@uconn.edu).

Published in Crop Sci. 43:272-281 (2003). greens were greatest when $\mathrm{P}$ and lime were withheld and $\mathrm{N}$ was applied at $400 \mathrm{~kg} \mathrm{ha}^{-1}$.

Creeping bentgrass response to applied $\mathrm{P}$ has been inconsistent. Waddington et al. (1978) reported that $\mathrm{P}$ fertilization had little effect on clipping yields from creeping bentgrass grown on a sandy loam-silty clay loam soil and managed as a putting green. Application of $\mathrm{P}$, however, increased bentgrass tissue $\mathrm{P}$ concentrations. Although creeping bentgrass growth was generally not responsive to $\mathrm{P}$ fertilization, annual bluegrass invasion was favored by $\mathrm{P}$ fertilization. Under fairway conditions, $\mathrm{P}$ fertilization did not significantly affect the growth or quality of creeping bentgrass on a loam soil (Dest and Guillard, 1987). Tissue P concentrations showed a significant increase to $\mathrm{P}$ fertilization in only one of three sampling periods, and the composition of the creeping bentgrass-annual bluegrass community was unaffected by 3 yr of P fertilization. Kuo et al. (1992) reported that creeping bentgrass root yields and lengths were greater than annual bluegrass grown in various mineral soils when the molar ratio of Olsen $\left(\mathrm{NaHCO}_{3}\right)$ extractable $\mathrm{P}$ :exchangeable $\mathrm{Al}$ was $<0.2$, but less when the ratios were higher. Creeping bentgrass root yields reached a maximum at a ratio of $\approx 0.1$, whereas annual bluegrass showed a steady increase of root yields with increasing molar ratios. Creeping bentgrass and annual bluegrass clipping yields and $\mathrm{P}$ uptakes were related to lime and P treatments on two acid soils (Kuo, 1993b). Response to $\mathrm{P}$ was enhanced by liming, with annual bluegrass benefiting more from the high lime and $\mathrm{P}$ treatments than creeping bentgrass.

There are only a few reported studies on creeping bentgrass response to $\mathrm{P}$ when grown on sand-based media. Christians et al. (1979) found no significant clipping, root, or quality responses of creeping bentgrass to applied $\mathrm{P}$ when grown in a sand media. According to the investigators, $\mathrm{P}$ was most likely adequate at the lowest rates used. No measurable response to $\mathrm{P}$ was observed by Christians et al. (1981) for creeping bentgrass grown on calcareous sand greens. A significant quadratic response of creeping bentgrass quality to increasing $\mathrm{P}$ concentrations, however, was reported by Fry et al. (1989) for a sand putting green. Response was greatest to the first increment of $\mathrm{P}$ fertilizer $\left(5 \mathrm{~kg} \mathrm{ha}^{-1} \mathrm{mo}^{-1}\right)$, but no further increase in quality was observed for rates greater than the first $\mathrm{P}$ application rate. On a mixed fescue $\{$ Festuca rubra var. commutata Gaudin $[=F$. rubra subsp. fallax (Thuill.) Nyman]\} and bentgrass $(A$. castellana Boiss. \& Reut.) sand green, P fertilization increased ground cover only at the highest $\mathrm{N}$ rate of 400

Abbreviations: CN, Cate-Nelson model; QRP, quadratic response and plateau model; STRI, Sports Turf Research Institute. 
$\mathrm{kg} \mathrm{ha}^{-1}$ (Colclough and Canaway, 1989). Phosphorus fertilization on a USGA-specified rootzone mix for greens did not increase the percentage cover of bentgrass compared with untreated plots as reported by Lodge et al. (1990). On a pure, uniform, medium-fine silica sand rootzone mix, however, Lodge et al. (1991) observed increased ground cover of bentgrass species when $\mathrm{P}$ was applied.

The above cited fertilizer studies have typically investigated bentgrass response to specific applied $\mathrm{P}$ fertilizer rates, but they usually have not reported the relationship of growth or quality responses to resultant extractable soil $\mathrm{P}$ concentrations from various treatment applications. Seeing that the foundation of turfgrass nutrient management is based primarily on soil testing programs (and to a limited extent on tissue testing) that utilize extractable soil nutrient concentrations, reporting on specific treatment effects without the inclusion of actual soil test values is, in our opinion, of limited value. There is a need for more calibration data on which to verify and modify existing soil test recommendations for turfgrasses. With the exception of the studies by Kuo et al. (1992) and Kuo (1993b), there is a paucity of information showing the relationship of creeping bentgrass growth and quality to extractable soil $\mathrm{P}$ concentrations. It is apparent from these studies that more research is required to increase our understanding of turfgrass fertility management based on soil $\mathrm{P}$ concentrations. Therefore, the objective of this study was to determine the relationship between extractable soil test $\mathrm{P}$ concentrations from a sand putting green, as determined by three different extraction methods, and various creeping bentgrass growth and quality measurements.

\section{MATERIALS AND METHODS}

A field experiment was conducted on a sand-based putting green nursery of the Shorehaven Country Club in Norwalk, CT, USA. The rootzone mix had a depth of $30 \mathrm{~cm}$ and was a ratio of 4:1, sand:organic matter by volume (27.2 $\mathrm{g}$ organic matter $\mathrm{kg}^{-1}$ rootzone mix). The organic matter is described as a Typic Medisaprist in the order Histosols (Fletcher, 1975). The nursery was seeded with 'Penncross' creeping bentgrass. The experiment was conducted $3 \mathrm{yr}$ after seeding and treatments were arranged as a $3 \times 3 \times 2 \times 2$ factorial with three residual soil $\mathrm{P}$ levels, three rates of applied $\mathrm{P}$, two rates of applied $\mathrm{K}$, and two $\mathrm{pH}$ levels set out as a split-plot design with four replications. Potassium rates were the main plots and the various combinations of residual soil $\mathrm{P}$, fertilizer $\mathrm{P}$ rates, and $\mathrm{pH}$ treatments were subplots. Plot size was 1.5 by $3.1 \mathrm{~m}$. The various combinations of treatments were selected to provide a wide range of extractable soil $\mathrm{P}$ concentrations by which to model bentgrass responses. Soil test results before treatment application indicated extractable $\mathrm{P}$ concentrations of $0.9,8.5$, and $4.5 \mathrm{mg} \mathrm{kg}^{-1}$ for the modified-Morgan (McIntosh, 1969), Mehlich-1 (Mehlich, 1953), and Bray-1 (Bray and Kurtz, 1945) extractants, respectively. The residual soil P and $\mathrm{pH}$ levels were established $3 \mathrm{yr}$ before imposition of the various $\mathrm{P}$ and $\mathrm{K}$ application rates. The three levels of residual soil $\mathrm{P}$ were established by applying triple superphosphate (0-46-0, N-P-K) to the plots before seeding at 0,59 , and $118 \mathrm{~kg} \mathrm{P} \mathrm{ha}^{-1}$ and raking into the sand to a $3-\mathrm{cm}$ depth. The two $\mathrm{pH}$ levels were established by applying aluminum sulfate at a rate of $3914 \mathrm{~kg} \mathrm{ha}^{-1}$ to half of the plots before planting and incorporat- ing into the surface to a depth of $3 \mathrm{~cm}$. This resulted in a soil $\mathrm{pH}$ of $\approx 5.0$. The remaining plots had a soil $\mathrm{pH}$ of 6.3 .

Three years after establishing the residual soil $\mathrm{P}$ and soil $\mathrm{pH}$ levels, fertilizer treatments with $\mathrm{P}$ and $\mathrm{K}$ were applied to the plots and continued for a 3-yr period. Fertilizer $\mathrm{P}$ was applied as triple superphosphate at 0,30 , and $60 \mathrm{~kg} \mathrm{P} \mathrm{ha}^{-1}$ in single applications each year. Potassium was withheld from half of the plots or applied five times in $3 \mathrm{yr}$ as muriate of potash (0-0-60) to supply $123 \mathrm{~kg} \mathrm{~K} \mathrm{ha}^{-1}$ with each application. Nitrogen fertilization rates varied each year, and $\mathrm{N}$ was supplied using ammonium nitrate (34-0-0) and Ureaform (38-0-0). In the year preceding the first season of data collection, ureaform was applied in Dec. to supply $146 \mathrm{~kg} \mathrm{~N} \mathrm{ha}^{-1}$. During the first year of data collection, ammonium nitrate was applied in June, August, and September to supply 29, 29, and $59 \mathrm{~kg}$ $\mathrm{N}$ ha $^{-1}$, respectively. During the second year of the study, ureaform was applied in April and Dec. to supply $122 \mathrm{~kg} \mathrm{~N}$ $\mathrm{ha}^{-1}$, and ammonium nitrate was applied in June, July, August, and September to supply 24, 24, 24, and $49 \mathrm{~kg} \mathrm{~N} \mathrm{ha}^{-1}$, respectively. In the third year of the study, ammonium nitrate was applied in May, June, July, and August to supply $24 \mathrm{~kg} \mathrm{~N} \mathrm{ha}^{-1}$ at each application. Irrigation was used to supplement rainfall as needed.

The plots were mowed at a height of $5.6 \mathrm{~mm}$ four times per week, and the clippings were removed. Clippings were collected in a grass catcher mounted on a putting green mower from a $1.32-\mathrm{m}^{2}$ area in the center of each plot to assess yield responses from a selected date in October during the first and second years of the study, and from a selected date in August during the third year. Yields represented $3 \mathrm{~d}$ of growth at each harvest. A subsample of the clippings was collected for tissue analysis and dried at $70^{\circ} \mathrm{C}$ until a constant weight was obtained. Samples were then ground in a Wiley mill to pass a 2-mm screen. A 300-mg sample was digested in a nitricperchloric acid mixture and the contents of $\mathrm{P}$ analyzed using the procedure described by Steckel and Flannery (1971). Shoot counts were measured by randomly collecting two $9.4-\mathrm{cm}^{2}$ plugs from the center of each plot in the fall of each year (September of Year 1, October of Year 2, and August of Year 3 ) using a Noer sampler. Uncompressed thatch was measured on the samples collected for shoot counts before the counts were made. Visual ratings for turf quality were made in the fall of each year (October of Years 1 and 2, and November of Year 3) using a scale of $1=$ very poor quality to $9=$ excellent quality. Quality ratings were based on turf density, color, annual bluegrass infestation, and disease incidence and severity. Visual ratings for leaf $\mathrm{P}$ deficiency symptoms used a scale of $1=$ no $\mathrm{P}$ deficiency symptoms (normal light green color) to $5=$ severe $\mathrm{P}$ deficiency symptoms (dark bluish or purplish green).

In the third year of the study, two sod plugs $\left(9.4 \mathrm{~cm}^{2}\right.$ each $)$ were obtained to a depth of $15 \mathrm{~cm}$ using a Noer sampler at the termination of the experiment to measure root weights. The plugs were placed on a screen and the soil was washed from the roots. The aerial portion of the plants and thatch were removed and the roots were dried at $70^{\circ} \mathrm{C}$ until a constant weight was obtained. The roots were weighed then ashed at $600^{\circ} \mathrm{C}$ for $2 \mathrm{~h}$. The ash weight was subtracted from the ovendry weight to determine the ash-free root dry weight. Soil samples were collected in October of each year from each plot to a depth of $8 \mathrm{~cm}$ with a $2-\mathrm{cm}$ diameter push auger. Ten soil samples were taken from each plot and mixed to provide a sample for soil analyses. The modified-Morgan, Mehlich-1, and Bray-1 extractants were used for $\mathrm{P}$ availability in the rootzone mix. The modified-Morgan is a buffered weak acid solution $\left(1.25 \mathrm{M} \mathrm{CH}_{3} \mathrm{COOH}+0.625 \mathrm{M} \mathrm{NH}_{4} \mathrm{OH}\right.$ at $\left.\mathrm{pH} 4.8\right)$ and used primarily for coarser-textured, acidic soils in the 
northeastern USA. The Bray-1 is a strong acid solution containing fluoride $\left(0.025 \mathrm{M} \mathrm{HCl}+0.03 \mathrm{M} \mathrm{NH}_{4} \mathrm{~F}\right)$ and used primarily on finer textured soils of the midwestern USA. The Mehlich-1 extractant is a strong double acid solution (0.05 M $\mathrm{HCl}+0.05 \mathrm{M} \mathrm{H}_{2} \mathrm{SO}_{4}$ ) used both on acidic coastal plain sandy soils and finer-textured Piedmont soils in the southeastern USA. Because of the stronger acid solutions, the Bray and Mehlich methods extract more $\mathrm{P}$ than the modified-Morgan method (Wolf and Beegle, 1995). Phosphorus in the extract was determined by a molybdenum-blue method as described by Hesse (1971).

Clipping yields and quality responses for each treatment were plotted or regressed on extractable soil P concentrations for each respective treatment. For model analyses, each data point represents the mean (4 replications) extractable soil $\mathrm{P}$ concentration associated with the mean response (4 replications) of any specific treatment combination. There were 36 different treatments $(3 \times 3 \times 2 \times 2)$, therefore each model is based on these 36 different points. Results are presented for each year and for the average response across all years. Relationship of response variables to extractable soil P concentrations was determined with the $\mathrm{CN}$ graphical method (Cate and Nelson, 1971) and with a QRP model. The ANOVA procedure of SAS (SAS Institute, 1990) was used to obtain maximum sum of squares for the $\mathrm{CN}$ method (Nelson and Anderson, 1977), and the SAS procedure NLIN (SAS Institute, 1990) was used for parameter estimates in the QRP model. Relative yields for clippings were obtained by determining the plateau yield estimated by the QRP model for each year and extractant and dividing the observed yields by the respective plateau yield. For the 3 -yr combined analysis, mean relative yields were obtained by averaging the relative yields from each individual year. Root weights were plotted or regressed only on the third-year mean soil extractable $\mathrm{P}$ concentrations. Although the experiment was conducted as a $3 \times 3 \times 2 \times 2$ factorial set out in a split-plot design, specific treatment effects or interactions among specific treatments or with years is not relevant in our case. The various treatments were selected only to provide a wide range of extractable soil $\mathrm{P}$ concentrations by which to model bentgrass growth and quality responses with QRP and CN methods.

\section{RESULTS AND DISCUSSION}

Application of the various treatments before and during the experiment resulted in a wide range of extractable soil $\mathrm{P}$ concentrations for the $3 \mathrm{yr}$ of the study $(0.5$ to $14 \mathrm{mg} \mathrm{kg}^{-1}$ for modified-Morgan, 7 to $84 \mathrm{mg} \mathrm{kg}^{-1}$ for Mehlich-1, and 2 to $112 \mathrm{mg} \mathrm{kg}^{-1}$ for Bray-1). The growth and quality of creeping bentgrass was affected by extractable soil P concentrations (Fig. 1-3). Responses were described relatively well by the CN and QRP models for most variables based on coefficients of determination (Table 1). The exceptions were for thatch in the second and third years of the study and for the relative clipping yields in all years. Critical concentrations of extractable $\mathrm{P}$ for all variables were greatest for the Mehlich-1 and least for the modified-Morgan extractant (Table 1). Critical concentrations were always lower for the CN model than the QRP model (Table 1). This is to be expected, because the critical concentration indicated by the $\mathrm{CN}$ model is the breakpoint between a low or high probability of observing a response to extractable P. Concentrations slightly before or after the vertical break usually are not at the maximum response, whereas the QRP model continues to show a response, albeit at a decreasing rate, until the maximum (plateau) response is reached.

\section{Shoot Counts}

Previous research has shown varied responses of bentgrass shoot counts to $\mathrm{P}$ application. Dest and Guillard (1987) did not find a significant effect of $P$ additions on creeping bentgrass shoot counts under fairway conditions on a loam soil with an initial modified-Morgan extractable $\mathrm{P}$ concentration of $10.7 \mathrm{mg} \mathrm{kg}^{-1}$. This was much greater than the critical concentration range for counts indicated by $\mathrm{CN}$ and QRP models for modifiedMorgan P (Fig. 1; Table 1) in our study and suggests that sufficient $\mathrm{P}$ was available for bentgrass requirements in the previous study. On sand greens, Colclough and Canaway (1989) observed an increase in bentgrass cover to $\mathrm{P}$ fertilization only at the highest $\mathrm{N}$ rate of $400 \mathrm{~kg}$ $\mathrm{ha}^{-1}$. Before treatment application, $0.5 \mathrm{M}$ acetic acid extractable $\mathrm{P}$ was $\approx 10.5 \mathrm{mg} \mathrm{kg}^{-1}$ [D. Lawson, Sports Turf Research Institute (STRI), 2000, personal communication]. Lodge et al. (1990) reported no significant increases in bentgrass percentage cover for a USGAspecified sand green with extractable $\mathrm{P}(0.5 \mathrm{M}$ acetic acid) that ranged from $\approx 4.8 \mathrm{mg} \mathrm{kg}^{-1}$ at the no-P treatment to $15.3 \mathrm{mg} \mathrm{kg}^{-1}$ at the highest $\mathrm{P}$ fertilizer rate (Lodge and Lawson, 1990; D. Lawson, STRI, 2000, personal communication). On a pure sand green, Lodge et al. (1991) reported an increase in bentgrass cover to $\mathrm{P}$ fertilization when the $0.5 \mathrm{M}$ acetic acid extractable $\mathrm{P}$ concentration of the rootzone mix before treatment application was $\approx 7.0 \mathrm{mg} \mathrm{kg}^{-1}$ (D. Lawson, STRI, 2000, personal communication). We cannot directly compare the $0.5 \mathrm{M}$ acetic acid extractable $\mathrm{P}$ concentrations with our results, but they would probably be slightly less than the extractable $\mathrm{P}$ concentrations from the modifiedMorgan extractant (which has a higher molarity of acetic acid). Our estimated critical concentrations were a relatively good predictor of shoot counts under these conditions.

\section{Thatch}

Greater unexplained variation was observed for thatch response and the modified-Morgan extractant than for the other response variables (Fig. 1-3; Table 1). We could find no other reports in the literature that related thatch thickness to extractable soil $\mathrm{P}$ concentrations. It is reasonable to assume, however, that an increase in thatch thickness would occur until the critical concentrations are reached because shoot and root growth were positively affected as $\mathrm{P}$ availability increased to the critical concentrations. Lodge and Baker (1991) reported that surface hardness of sand greens decreased more with $\mathrm{P}$ fertilization and varying $\mathrm{N}$ rates than for these $\mathrm{N}$ rates without $\mathrm{P}$. Although thatch thickness was not reported in their study, it may be possible that the reduction in surface hardness was related to an increase in thatch thickness as $\mathrm{P}$ rates increased in combination with higher $\mathrm{N}$ rates. 

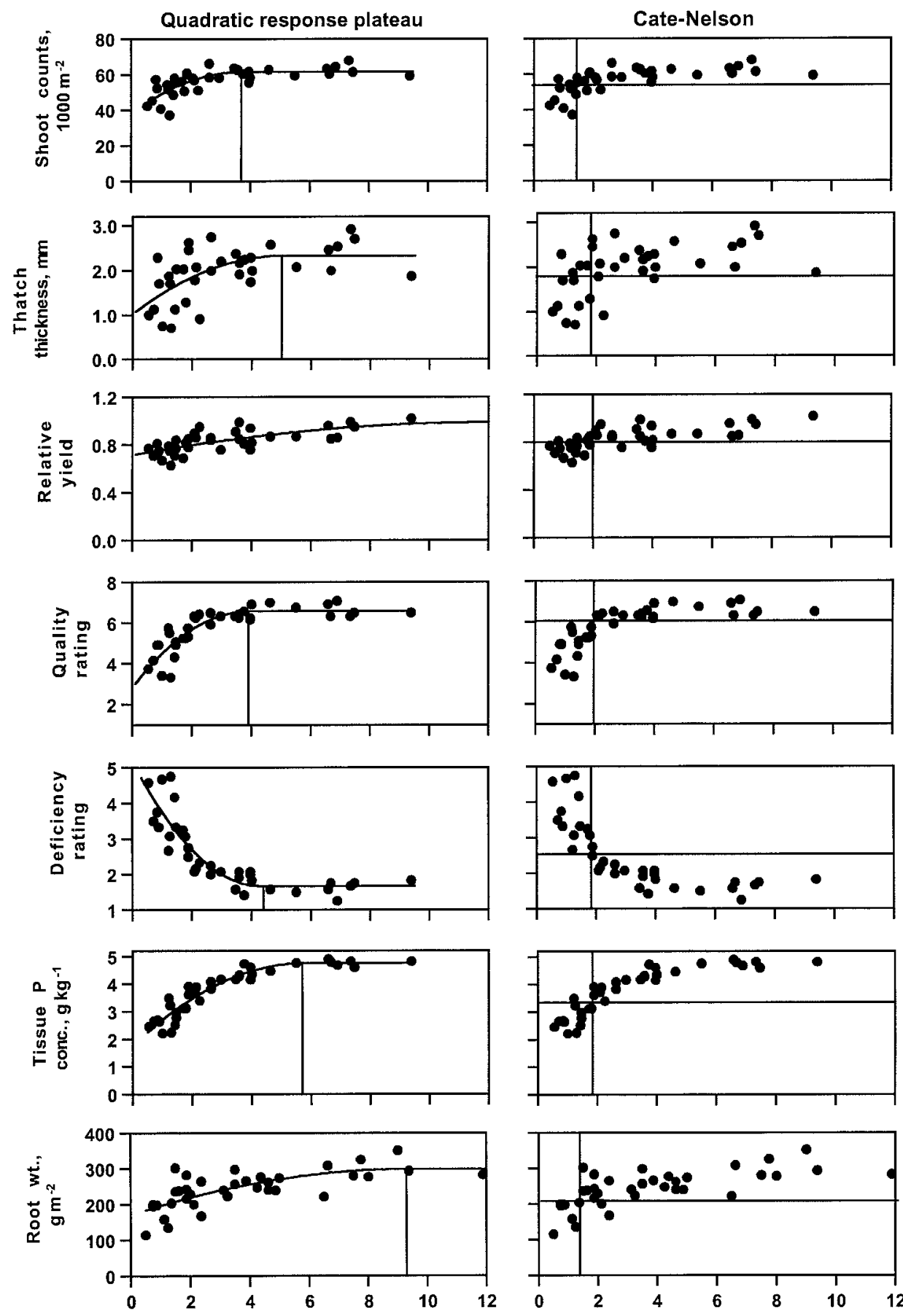

modified-Morgan extractable $P$, mg kg-1 $^{-1}$

Fig. 1. Quadratic response plateau and Cate-Nelson plots of creeping bentgrass growth and quality responses to modified-Morgan extractable $P$ concentrations averaged across three years. Vertical lines to the $x$-axes in the plots indicate the critical concentration of extractable $P$.

\section{Relative Clipping Yields}

The QRP and CN methods did not model relative clipping yield data well for any extractant because yields showed a gradually increasing response to extractable soil P concentrations; a plateau did not exist within the data range or was established toward the far-right range of data. Confidence in the critical concentrations at the far-right range of data is low because there were few data to establish a break point for the plateau. Also, only one selected harvest was taken in the fall of each year to assess yield response, and this may not have adequately estimated the clipping response compared with yield response across the entire growing season. Although clipping yields are used to determine turfgrass response to nutrient availability, fertilizing for maximum clipping yields may not always be desirable, and in fact, may be detrimental to certain functional quality measurements in bentgrass such as ball roll and green 

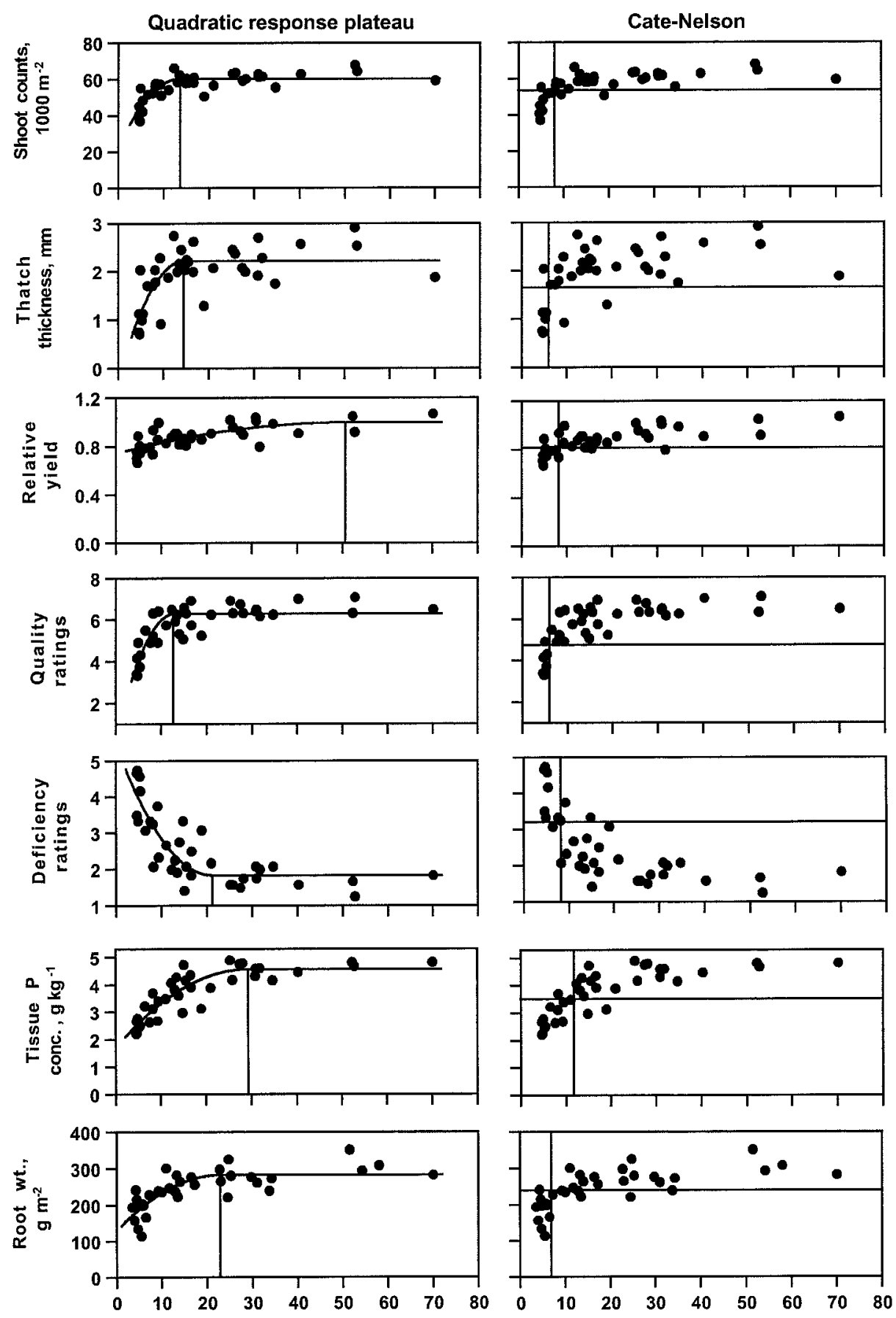

\section{Bray-1 extractable $P$, mg kg-1 $^{-1}$}

Fig. 2. Quadratic response plateau and Cate-Nelson plots of creeping bentgrass growth and quality responses to Bray-1 extractable $P$ concentrations averaged across $3 \mathrm{yr}$. Vertical lines to the $x$-axes in the plots indicate the critical concentration of extractable $\mathbf{P}$.

speed. Lodge and Baker (1991) reported that ball roll length, in response to $\mathrm{N}$, decreased more on sand greens fertilized with $\mathrm{P}$ than on greens from which $\mathrm{P}$ was withheld. The critical concentration suggested by the $\mathrm{CN}$ model may be a better guide than the QRP model (even though it may be less reliable in predicting yield) if green speed is one of the primary influencing factor on bentgrass management. This is because a lower critical level of extractable $\mathrm{P}$ is suggested by the $\mathrm{CN}$ model.
Ball roll can also be affected by Poa апnиa in greens. In our case, the test plots were free of Poa апnиа throughout the duration of the experiment and was not a factor that influenced functional quality measurements.

The critical soil concentrations indicated by the $\mathrm{CN}$ model suggest that sufficient extractable $\mathrm{P}$ was present in the studies of Waddington et al. (1978; $12 \mathrm{mg} \mathrm{kg}^{-1}$ Bray-1 extractable $\mathrm{P}$ in the no-P treatment) and Christians et al. (1981; Bray-1 extractable P of $12 \mathrm{mg} \mathrm{kg}-1$ 

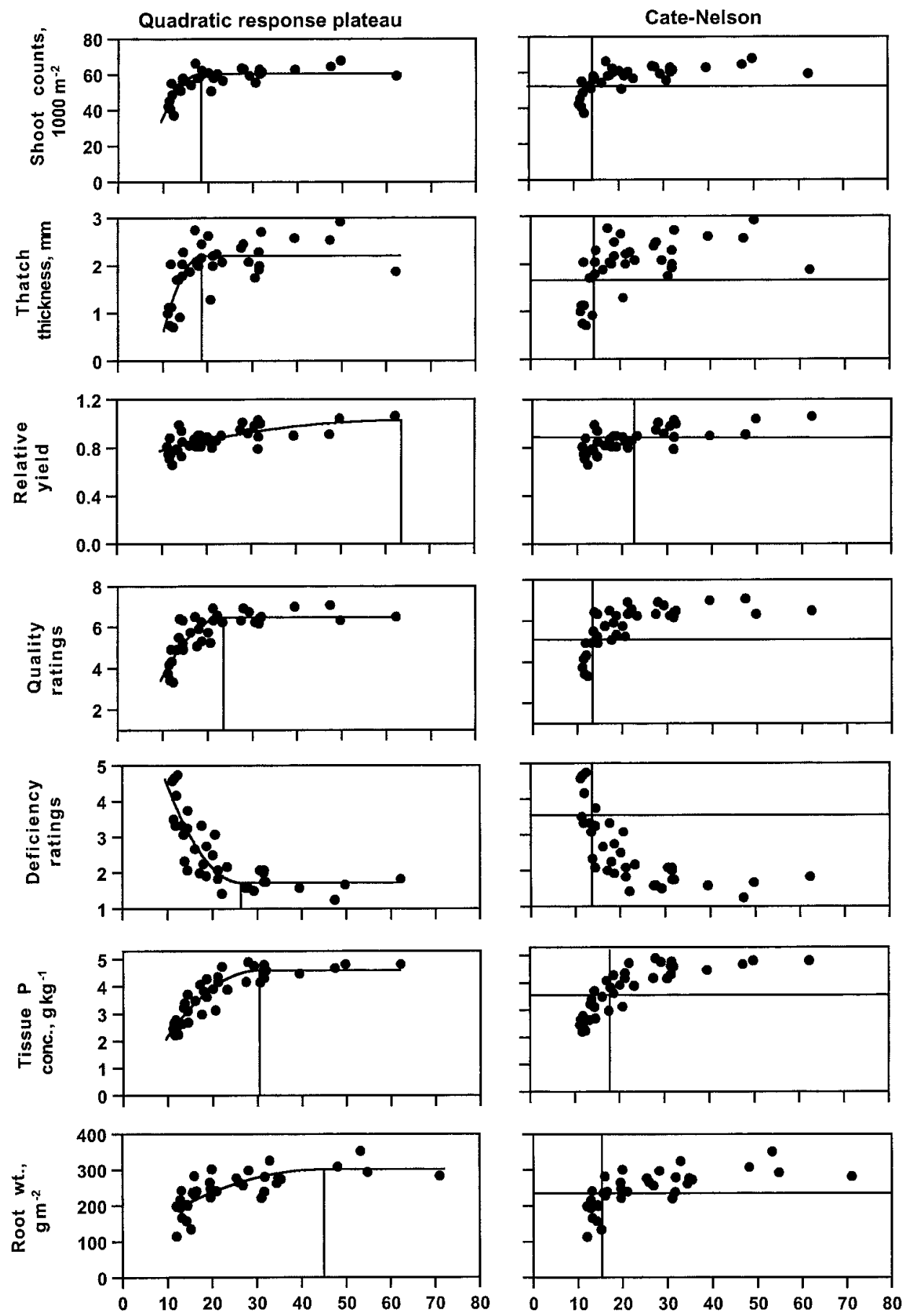

Mehlich-1 extractable $\mathbf{P}, \mathrm{mg} \mathrm{kg}^{-1}$

Fig. 3. Quadratic response plateau and Cate-Nelson plots of creeping bentgrass growth and quality responses to Mehlich-1 extractable $P$ concentrations averaged across 3 yr. Vertical lines to the $x$-axes in the plots indicate the critical concentration of extractable P.

and $\mathrm{pH}$ of 8.0) to meet growth requirements of creeping bentgrass. This probably explains why no yield responses were observed in these studies. Kuo (1993b) reported Olsen-extractable $\mathrm{P}$ concentrations at $95 \%$ of maximum clipping yields from 2.8 to $4.8 \mathrm{mg} \mathrm{kg}$. Although we did not test the Olsen method, these values are between the critical concentrations indicated by the $\mathrm{CN}$ model for the modified-Morgan and Bray-1 extractants.

\section{Fall Quality Ratings}

We deemed a quality rating of six and above to be acceptable for putting green standards. In this respect, acceptable quality could be obtained at less than the critical concentrations predicted by the QRP models and nearer to the critical concentrations indicated by the CN models (Fig. 1-3; Table 1). This would be an important consideration in the management of bent- 
Table 1. Critical levels of extractable $P$, coefficients of determination $\left(R^{2}\right)$, and probability values from three different extractants for Cate-Nelson and quadratic response and plateau models used on a sand-based putting green.

\begin{tabular}{|c|c|c|c|c|c|c|c|c|c|c|c|c|c|}
\hline & \multicolumn{4}{|c|}{ Counts } & \multicolumn{4}{|c|}{ Thatch } & \multicolumn{4}{|c|}{ Relative yield } & \\
\hline & Year 1 & Year 2 & Year 3 & Mean $\dagger$ & Year 1 & Year 2 & Year 3 & Mean $\dagger$ & Year 1 & Year 2 & Year 3 & Mean $\dagger$ & \\
\hline & & & & & & Quadratic & Plateau & & & & & & \\
\hline \multicolumn{14}{|l|}{ Morgan } \\
\hline $\begin{array}{l}\text { Critical } \\
R^{2}\end{array}$ & $\begin{array}{l}4.9 \\
0.644\end{array}$ & $\begin{array}{l}3.1 \\
0.286\end{array}$ & $\begin{array}{l}4.2 \\
0.563\end{array}$ & 3.7 & $\begin{array}{l}5.8 \\
0.427\end{array}$ & $\begin{array}{l}5.4 \\
0.166\end{array}$ & \multirow[t]{2}{*}{$-\dagger$} & $\begin{array}{l}5.1 \\
0.356\end{array}$ & $\begin{array}{l}4.0 \\
0.273\end{array}$ & $\begin{array}{l}7.1 \\
0.297\end{array}$ & $\begin{array}{l}3.9 \\
0.347\end{array}$ & 12.0 & \\
\hline $\begin{array}{l}R^{2} \\
P \text { value }\end{array}$ & $\begin{array}{l}\mathbf{0 . 6 4 4} \\
<\mathbf{0 . 0 0 0 1}\end{array}$ & $\begin{array}{l}0.286 \\
0.0039\end{array}$ & $\begin{array}{l}\mathbf{0 . 5 6 3} \\
<\mathbf{0 . 0 0 0 1}\end{array}$ & $<0.0001$ & $\begin{array}{l}0.427 \\
0.0001\end{array}$ & $\begin{array}{l}0.166 \\
0.0497\end{array}$ & & $\begin{array}{l}0.356 \\
0.0007\end{array}$ & $\begin{array}{l}0.273 \\
0.0052\end{array}$ & $\begin{array}{l}0.297 \\
0.0030\end{array}$ & $\begin{array}{l}0.347 \\
0.0009\end{array}$ & $\begin{array}{c}0.450 \\
<\mathbf{0 . 0 0 0 1}\end{array}$ & \\
\hline \multicolumn{14}{|l|}{ Bray-1 } \\
\hline Critical & 23.0 & 13.2 & 10.7 & 13.6 & 23.4 & 16.9 & -+ & 14.4 & 42.7 & 41.7 & 26.6 & 52.5 & \\
\hline $\boldsymbol{R}^{2}$ & 0.738 & 0.750 & 0.546 & 0.683 & 0.532 & 0.237 & & 0.515 & 0.270 & 0.285 & 0.265 & 0.494 & \\
\hline$P$ value & $<0.0001$ & 0.0001 & $<0.0001$ & $<\mathbf{0 . 0 0 0 1}$ & $<\mathbf{0 . 0 0 0 1}$ & 0.0116 & & $<\mathbf{0 . 0 0 0 1}$ & 0.0055 & 0.0040 & 0.0063 & $<\mathbf{0 . 0 0 0 1}$ & \\
\hline \multirow{6}{*}{$\begin{array}{c}\text { Mehlich-1 } \\
\text { Critical } \\
R^{2} \\
P \text { value }\end{array}$} & & & & & & & & & & & & & \multirow{5}{*}{ Root wt. } \\
\hline & 22.8 & 18.4 & 22.3 & 18.5 & 23.2 & 25.2 & $-\ddagger$ & 18.7 & 38.3 & 69.3 & 35.3 & 63.6 & \\
\hline & 0.711 & 0.706 & 0.481 & 0.675 & 0.493 & 0.254 & & 0.538 & 0.280 & 0.235 & 0.249 & 0.473 & \\
\hline & $<0.0001$ & $<0.0001$ & $<\mathbf{0 . 0 0 0 1}$ & $<\mathbf{0 . 0 0 0 1}$ & $<0.0001$ & 0.0079 & & $<0.0001$ & 0.0045 & 0.0121 & 0.0088 & $<0.0001$ & \\
\hline & \multicolumn{4}{|c|}{ Quality ratings } & \multicolumn{4}{|c|}{ Deficiency ratings } & \multicolumn{4}{|c|}{ Tissue $\mathbf{P}$} & \\
\hline & Year 1 & Year 2 & Year 3 & Mean $\dagger$ & Year 1 & Year 2 & Year 3 & Mean $\dagger$ & Year 1 & Year 2 & Year 3 & Mean $\dagger$ & Year 3 \\
\hline & & & & & & Quadratic & Plateau - & & & & & & \\
\hline Morgan & & & & & & & & & & & & & \\
\hline Critical & 3.6 & 2.2 & 4.5 & 3.9 & 4.5 & 2.1 & 5.0 & 4.3 & 8.5 & 3.4 & 5.1 & 5.7 & 9.3 \\
\hline $\boldsymbol{R}^{2}$ & 0.552 & 0.645 & 0.535 & 0.758 & 0.587 & 0.768 & 0.699 & 0.802 & 0.864 & 0.871 & 0.821 & 0.894 & 0.508 \\
\hline$P$ value & $<0.0001$ & $<\mathbf{0 . 0 0 0 1}$ & $<\mathbf{0 . 0 0 0 1}$ & $<0.0001$ & $<\mathbf{0 . 0 0 0 1}$ & $<0.0001$ & $<\mathbf{0 . 0 0 0 1}$ & $<0.0001$ & $<0.0001$ & $<0.0001$ & $<0.0001$ & $<0.0001$ & $<\mathbf{0 . 0 0 0 1}$ \\
\hline Bray-1 & & & & & & & & & & & & & \\
\hline Critical & 12.8 & 12.1 & 9.4 & 12.7 & 12.0 & 15.2 & 16.3 & 21.3 & 38.5 & 29.5 & 17.7 & 29.1 & 22.9 \\
\hline$R^{2}$ & 0.793 & 0.555 & 0.488 & 0.708 & 0.735 & 0.657 & 0.665 & 0.706 & 0.764 & 0.701 & 0.775 & 0.777 & 0.606 \\
\hline$P$ value & $<0.0001$ & $<\mathbf{0 . 0 0 0 1}$ & $<\mathbf{0 . 0 0 0 1}$ & $<0.0001$ & $<\mathbf{0 . 0 0 0 1}$ & $<0.0001$ & $<\mathbf{0 . 0 0 0 1}$ & $<\mathbf{0 . 0 0 0 1}$ & $<\mathbf{0 . 0 0 0 1}$ & $<0.0001$ & $<\mathbf{0 . 0 0 0 1}$ & $<\mathbf{0 . 0 0 0 1}$ & $<0.0001$ \\
\hline Mehlich-1 & & & & & & & & & & & & & \\
\hline Critical & 13.9 & & 24.0 & 23.6 & 12.7 & 24.0 & 26.5 & 26.3 & 34.5 & 30.2 & 26.3 & 30.4 & 45.1 \\
\hline$R^{2}$ & 0.785 & 0.453 & 0.442 & 0.689 & 0.693 & 0.659 & 0.670 & 0.734 & 0.769 & 0.736 & 0.803 & 0.830 & 0.568 \\
\hline$P$ value & $<\mathbf{0 . 0 0 0 1}$ & $<0.0001$ & $<0.0001$ & $<\mathbf{0 . 0 0 0 1}$ & $<\mathbf{0 . 0 0 0 1}$ & $<\mathbf{0 . 0 0 0 1}$ & $<0.0001$ & $<\mathbf{0 . 0 0 0 1}$ & $<0.0001$ & $<\mathbf{0 . 0 0 0 1}$ & $<0.0001$ & $<\mathbf{0 . 0 0 0 1}$ & $<\mathbf{0 . 0 0 0 1}$ \\
\hline & & Co & unts & & & Tha & & & & Relati & e yield & & \\
\hline & Year 1 & Year 2 & Year 3 & Mean $\dagger$ & Year 1 & Year 2 & Year 3 & Mean $\dagger$ & Year 1 & Year 2 & Year 3 & Mean $\dagger$ & \\
\hline & & & & & & - Cate- $\mathbf{N}$ & elson & & & & & & \\
\hline Morgan & & & & & & & & & & & & & \\
\hline Critical & 2.1 & 0.81 & 2.4 & 1.8 & 1.7 & 2.3 & 2.4 & 2.4 & 2.6 & 1.2 & 1.9 & 2.0 & \\
\hline $\boldsymbol{R}^{2}$ & 0.534 & 0.633 & 0.542 & 0.526 & 0.414 & 0.161 & 0.076 & 0.315 & 0.308 & 0.336 & 0.414 & 0.481 & \\
\hline$P$ value & $<\mathbf{0 . 0 0 0 1}$ & $<0.0001$ & $<0.0001$ & $<\mathbf{0 . 0 0 0 1}$ & $<0.0001$ & 0.0152 & 0.1031 & 0.0004 & 0.0004 & 0.0002 & $<0.0001$ & $<\mathbf{0 . 0 0 0 1}$ & \\
\hline Bray-1 & & & & & & & & & & & & & \\
\hline Critical & & & 5.6 & 7.0 & 15.2 & 6.6 & 6.6 & 6.0 & 11.0 & 8.4 & 5.6 & 8.2 & \\
\hline$R^{2}$ & & 0.580 & 0.541 & 0.584 & 0.514 & 0.245 & 0.176 & 0.435 & 0.325 & 0.217 & 0.429 & 0.437 & \\
\hline$P$ value & $<\mathbf{0 . 0 0 0 1}$ & $<\mathbf{0 . 0 0 0 1}$ & $<\mathbf{0 . 0 0 0 1}$ & $<\mathbf{0 . 0 0 0 1}$ & $<0.0001$ & 0.0022 & 0.0108 & $<\mathbf{0 . 0 0 0 1}$ & 0.0003 & 0.0042 & $<0.0001$ & $<\mathbf{0 . 0 0 0 1}$ & \\
\hline Mehlich-1 & & & & & & & & & & & & & \\
\hline Critical & 13.4 & 11.6 & 16.1 & 14.1 & 16.0 & 11.6 & 16.1 & 14.1 & 13.4 & 25.7 & 12.6 & 22.7 & \\
\hline$R^{2}$ & 0.620 & 0.545 & & 0.625 & 0.514 & 0.234 & 0.121 & & 0.326 & 0.297 & 0.261 & 0.398 & \\
\hline$P$ value & $<0.0001$ & $<0.0001$ & $<0.0001$ & $<\mathbf{0 . 0 0 0 1}$ & $<\mathbf{0 . 0 0 0 1}$ & 0.0028 & 0.0378 & $<0.0001$ & 0.0003 & 0.0006 & 0.0015 & $<0.0001$ & \\
\hline & & Quality & ratings & & & Deficien & y ratings & & & Tiss & ue $P$ & & Root wt. \\
\hline & Year 1 & Year 2 & Year 3 & Mean $\dagger$ & Year 1 & Year 2 & Year 3 & Mean $\dagger$ & Year 1 & Year 2 & Year 3 & Mean $\dagger$ & Year 3 \\
\hline & & & & & & - Cate- $\mathbf{N}$ & elson - & & & & & & \\
\hline Morgan & & & & & & & & & & & & & \\
\hline Critical & 2.1 & 1.3 & 1.9 & 2.0 & 2.1 & 1.1 & 1.9 & 1.8 & 3.6 & 1.3 & 1.9 & 1.8 & 1.4 \\
\hline & & 0.515 & 0.581 & & 0.516 & 0.585 & 0.740 & 0.751 & & & & & 0.466 \\
\hline$P$ value & $<\mathbf{0 . 0 0 0 1}$ & $<0.0001$ & $<0.0001$ & $<0.0001$ & $<\mathbf{0 . 0 0 0 1}$ & $<\mathbf{0 . 0 0 0 1}$ & $<0.0001$ & $<\mathbf{0 . 0 0 0 1}$ & $<\mathbf{0 . 0 0 0 1}$ & $<\mathbf{0 . 0 0 0 1}$ & $<\mathbf{0 . 0 0 0 1}$ & $<\mathbf{0 . 0 0 0 1}$ & $<\mathbf{0 . 0 0 0 1}$ \\
\hline Bray-1 & & & & & & & & & & & & & \\
\hline Critical & 6.6 & 6.6 & 5.6 & 6.0 & 7.8 & 8.4 & 7.5 & 8.2 & 17.1 & 9.1 & 7.5 & 11.7 & 6.9 \\
\hline $\boldsymbol{R}^{2}$ & 0.781 & 0.516 & 0.529 & 0.636 & 0.724 & 0.540 & 0.638 & 0.615 & 0.700 & 0.430 & 0.702 & 0.649 & 0.566 \\
\hline$P$ value & $<\mathbf{0 . 0 0 0 1}$ & $<\mathbf{0 . 0 0 0 1}$ & $<\mathbf{0 . 0 0 0 1}$ & $<\mathbf{0 . 0 0 0 1}$ & $<\mathbf{0 . 0 0 0 1}$ & $<\mathbf{0 . 0 0 0 1}$ & $<\mathbf{0 . 0 0 0 1}$ & $<\mathbf{0 . 0 0 0 1}$ & $<\mathbf{0 . 0 0 0 1}$ & $<\mathbf{0 . 0 0 0 1}$ & $<\mathbf{0 . 0 0 0 1}$ & $<0.0001$ & $<\mathbf{0 . 0 0 0 1}$ \\
\hline Mehlich-1 & & & & & & & & & & & & & \\
\hline Critical & & & & & 10.6 & & 16.1 & 15.3 & & 21.8 & 15.1 & 17.8 & 15.4 \\
\hline $\boldsymbol{R}^{2}$ & 0.781 & 0.424 & 0.477 & 0.657 & 0.637 & 0.558 & 0.692 & 0.567 & 0.700 & 0.575 & 0.749 & 0.666 & 0.576 \\
\hline$P$ value & $<0.0001$ & $<0.0001$ & $<0.0001$ & $<\mathbf{0 . 0 0 0 1}$ & $<\mathbf{0 . 0 0 0 1}$ & $<0.0001$ & $<0.0001$ & $<0.0001$ & $<0.0001$ & $<0.0001$ & $<0.0001$ & $<0.0001$ & $<\mathbf{0 . 0 0 0 1}$ \\
\hline
\end{tabular}

$\dagger$ Mean based on response values averaged across three years; not arithmetic mean of individual critical values for each year.

\$ Model not applicable.

grass greens because annual bluegrass populations increase with greater availability of soil P (Goss et al., 1975; Waddington et al., 1978; Dest and Allinson, 1981; Lodge et al., 1991; Kuo et al., 1992; Kuo, 1993b). If annual bluegrass was considered undesirable in a creep- ing bentgrass stand, the goal would be to maintain soil $\mathrm{P}$ at the minimum or slightly less than the critical concentrations to give advantage to the bentgrass. If the goal is to maintain annual bluegrass populations, then $\mathrm{P}$ concentrations should be maintained at greater than our 
critical concentrations. Both models gave better fits with the modified-Morgan data for quality ratings than with the Mehlich-1 or Bray-1 data (Table 1).

Christians et al. (1981) did not find any significant quality responses for creeping bentgrass on calcareous sand greens when initial Bray- 1 extractable $\mathrm{P}$ concentrations were $12 \mathrm{mg} \mathrm{kg}^{-1}$. On a loam soil with modifiedMorgan extractable $\mathrm{P}$ at $10.7 \mathrm{mg} \mathrm{kg}^{-1}$, quality responses of creeping bentgrass were not affected by $\mathrm{P}$ fertilization (Dest and Guillard; 1987). Our models suggest that extractable soil P was a good indicator of creeping bentgrass quality in these studies. Fry et al. (1989) reported that creeping bentgrass quality improved with addition of $\mathrm{P}$ on sand-based media putting greens when extractable $\mathrm{P}$ was $<5 \mathrm{mg} \mathrm{kg}^{-1}$. No further improvement in quality was observed when extractable $\mathrm{P}$ ranged from 5 to $16 \mathrm{mg} \mathrm{kg}^{-1}$. Although the extractant used by Fry et al. (1989) was ammonium bicarbonate-DTPA (J. Self, pers. commun., 2001), these results would fall within our estimated critical concentrations.

\section{P Deficiency Ratings}

Similar to quality ratings, both models gave better fits with the modified-Morgan data for deficiency ratings than with the Mehlich-1 or Bray-1 data (Table 1). Creeping bentgrass growing in plots where the extractable $\mathrm{P}$ was less than the critical concentration consistently displayed more bluish and purplish green leaf blades than the plots where extractable $\mathrm{P}$ was greater than the critical concentrations. Leaf blade color in plots where extractable $\mathrm{P}$ was greater than the critical concentrations was a lighter green as is typical for healthy bentgrass turf. Color ratings in the studies of Waddington et al. (1978) and Dest and Guillard (1987) can be correlated to the deficiency rating critical concentrations as indicated for the modified-Morgan and Bray-1 extractants by the CN and QRP models (Fig. 1, 2; Table 1). Creeping bentgrass receiving $\mathrm{P}$ fertilization was rated as having a lighter green color than creeping bentgrass not fertilized with $\mathrm{P}$ when Bray-1 extractable $\mathrm{P}$ ranged from $12 \mathrm{mg} \mathrm{kg}^{-1}$ on the no-P plots and up to $94 \mathrm{mg}$ $\mathrm{kg}^{-1}$ with the $\mathrm{P}$ fertilized plots (Waddington et al., 1978). With a modified-Morgan extractable $\mathrm{P}$ concentration at $10.7 \mathrm{mg} \mathrm{kg}^{-1}$ before $\mathrm{P}$ fertilization, Dest and Guillard (1987) found no change in color of creeping bentgrass when $\mathrm{P}$ fertilizer was applied. Sufficient $\mathrm{P}$ was most likely available for bentgrass in that study because extractable $\mathrm{P}$ concentrations for the modified-Morgan method were well above our estimates of critical $\mathrm{P}$ concentrations based on $\mathrm{CN}$ and QRP models (Fig. 1, Table 1).

\section{Tissue P Concentrations}

Our data indicate that the sufficiency concentration for tissue $\mathrm{P}$ concentrations of creeping bentgrass falls within the sufficiency range of 3.0 to $5.5 \mathrm{~g} \mathrm{~kg}^{-1}$ for turfgrasses as suggested by Jones (1980). The CN and QRP models indicated tissue $\mathrm{P}$ concentrations of $\approx 3.3$ to $3.6 \mathrm{~g} \mathrm{~kg}^{-1}$ and 4.6 to $4.8 \mathrm{~g} \mathrm{~kg}^{-1}$, respectively, at the critical concentration of soil extractable $\mathrm{P}$ and greater for the three extractants (Fig. 1-3; Table 1). Across four acidic soils with varying Olsen extractable $\mathrm{P}$ concentrations, Kuo (1993a) also showed that tissue P concentrations of 3.0 to $5.5 \mathrm{~g} \mathrm{~kg}^{-1}$ were sufficient for maximizing growth of bentgrass. This agrees with both Jones (1980) and our suggested sufficiency ranges for tissue $\mathrm{P}$ concentrations. Application of our critical soil concentrations for tissue P concentrations in other studies would help to explain the lack of a creeping bentgrass response to P fertilization. Waddington et al. (1978) reported few growth increases in bentgrass with a tissue $\mathrm{P}$ concentration of $5.0 \mathrm{~g} \mathrm{~kg}^{-1}$ at the zero $\mathrm{P}$ treatment $\left(12 \mathrm{mg} \mathrm{kg}^{-1}\right.$, Bray-1) and $7.5 \mathrm{~g} \mathrm{~kg}^{-1}$ at the first increment of $P(24 \mathrm{mg}$ $\mathrm{kg}^{-1}$, Bray-1). When modified-Morgan extractable P was $10.7 \mathrm{mg} \mathrm{kg}^{-1}$, Dest and Guillard (1987) found that creeping bentgrass tissue $\mathrm{P}$ concentrations ranged from 4.1 to $5.3 \mathrm{~g} \mathrm{~kg}^{-1}$ in the no-P treatments, and no growth or quality increases were observed when P was applied. Kuo et al. (1992) considered the effect of exchangeable $\mathrm{Al}$ and Olsen extractable $\mathrm{P}$ on creeping bentgrass tissue $\mathrm{P}$ concentrations. When the molar ratio of Olsen extractable $\mathrm{P}$ :exchangeable $\mathrm{Al}$ reached $\approx 0.2$ and beyond, tissue $\mathrm{P}$ concentrations of creeping bentgrass were maximized at $\approx 2.5$ to $3 \mathrm{~g} \mathrm{~kg}^{-1}$.

As with quality and deficiency ratings, both models fit the modified-Morgan data better for tissue $\mathrm{P}$ concentrations than the Mehlich-1 or Bray-1 data (Table 1). This suggests that the weaker-acid, modified-Morgan extractant may more accurately estimate quality and tissue $\mathrm{P}$ responses in bentgrass grown on sand-based greens than stronger-acid extractants.

\section{Root Weights}

Few current studies are reported for the response of creeping bentgrass roots to $\mathrm{P}$ fertilization. Early research, however, indicates few significant positive relationships between the amount of available soil $\mathrm{P}$ and root growth in creeping bentgrass (Sprague, 1933; Bell and DeFrance, 1944; Holt and Davis, 1948). Christians et al. (1981) did not find any significant root responses for creeping bentgrass on calcareous sand greens when initial Bray-1 extractable P concentrations were $12 \mathrm{mg}$ $\mathrm{kg}^{-1}$. Our critical concentrations for Bray-1 extractable $\mathrm{P}$, as estimated by the $\mathrm{CN}$ model, would suggest that sufficient $\mathrm{P}$ was available for root development in their study. There are data to show, however, that the relationship between extractable $\mathrm{P}$ and exchangeable $\mathrm{Al}$ may be more important in predicting bentgrass root responses than with extractable $\mathrm{P}$ concentrations alone. With various mineral soils, Kuo et al. (1992) reported that creeping bentgrass root yields reached a maximum when the molar ratio of Olsen extractable P:exchangeable $\mathrm{Al}$ was at a ratio of $\approx 0.1$.

\section{Correlation between Extractants}

Extractable P was highly correlated among the three different extracting methods (Fig. 4). On average, Mehlich-1 and Bray-1 extractable $\mathrm{P}$ was four to six times greater than modified-Morgan extractable $\mathrm{P}$. The Mehlich-1 and Bray-1 extractable $\mathrm{P}$ concentrations were 


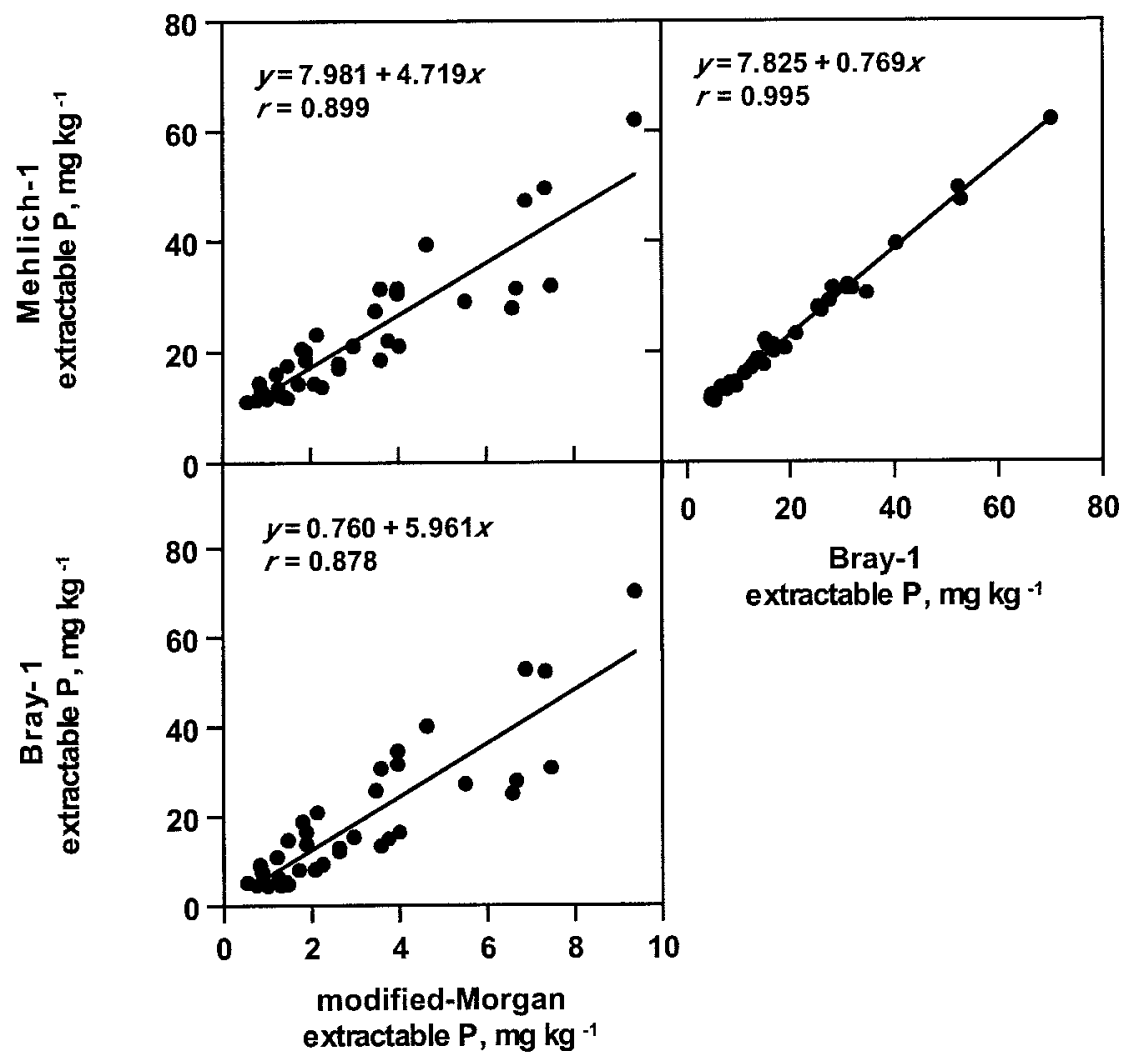

Fig. 4. Correlation plots between extractable $P$ concentrations from a sand putting green as determined by the modified-Morgan, Mehlich-1, and Bray-1 extractants averaged across 3 yr.

most closely related, with Bray-P being on average 1.3 times greater than Mehlich-1 extractable P. Greater amounts of $\mathrm{P}$ are extracted from mineral soils with Bray and Mehlich extractants than from the modified-Morgan extractant (Wolf and Beegle, 1995). We found this to be the case also for sand-based media.

\section{SUMMARY AND CONCLUSIONS}

We obtained good relationships between fall soil extractable $\mathrm{P}$ and fall growth and quality responses of creeping bentgrass grown in a sand-based media using modified-Morgan, Mehlich-1, and Bray-1 extracting solutions. The critical concentrations estimated by the $\mathrm{CN}$ and QRP models give a benchmark of extractable soil or media $\mathrm{P}$ to guide $\mathrm{P}$ fertilization of creeping bentgrass. Selection of a particular critical extractable soil $\mathrm{P}$ concentration would depend on the quality or growth variable(s) that is (are) most important to the individual turfgrass manager. Although our data were based on fall sampling, application of our estimated critical concentrations to growth and quality response variables substantiates observed responses or provides an explanation for the lack of response in most previously reported $\mathrm{P}$ studies with bentgrass, regardless of growing media or time of year. Until more studies are completed at different times of the year, our values based on fall sampling provide a good guide for $\mathrm{P}$ management of bentgrass for any season. It should be noted also that additional data is required for root responses, in that our estimates are based on only $1 \mathrm{yr}$ of data.

Magdoff et al. (1999) have shown that the amount of
$\mathrm{P}$ needed to increase modified-Morgan extractable $\mathrm{P}$ by a certain amount was directly related to the amount of $\mathrm{Al}$ in the Morgan extract. Our tests did not include effects on $\mathrm{P}$ availability by exchangeable or reactive $\mathrm{Al}$. In all likelihood, $\mathrm{Al}$ concentrations would probably be low in the sands used in our study and not an important consideration for soil $\mathrm{P}$ analyses. The work of Kuo et al. (1992) and Kuo (1993b), however, indicate the importance of including this variable when testing turfgrass response to extractable soil $\mathrm{P}$ on finer-textured mineral soils. It was also shown by Magdoff et al. (1999) that P availability to plants was more closely related to modified-Morgan extractable $\mathrm{P}$ than $\mathrm{P}$ extracted by Mehlich or Bray solutions. We found that the $\mathrm{CN}$ and $\mathrm{QRP}$ models gave better fits with modified-Morgan extractable $\mathrm{P}$ for bentgrass quality ratings, deficiency ratings, and tissue $\mathrm{P}$ concentrations than $\mathrm{P}$ extracted by the Mehlich or Bray extracts. This suggests that the modified-Morgan extractant may have advantages over other stronger acid extractants when used on sand-based media. More research is needed to refine fertilizer recommendations for creeping bentgrass grown in soil or sandbased media. The data from our study should help to eliminate the discrepancies in $\mathrm{P}$ fertilization recommendations between different soil testing laboratories using the same extractant for bentgrass grown in sandbased media.

\section{ACKNOWLEDGMENTS}

The authors thank Robert Phipps, past golf course superintendent, and the Shorehaven Country Club for providing space and maintenance support for the project. 


\section{REFERENCES}

Bell, R.S., and J.A. DeFrance. 1944. Influence of fertilizers on the accumulation of roots from closely clipped bent grasses and on the quality of the turf. Soil Sci. 58:17-24.

Bray, R.H., and L.T. Kurtz. 1945. Determination of total, organic and available forms of phosphorus in soils. Soil Sci. 59:39-45.

Cate, R.B., and L.A. Nelson. 1971. A simple statistical procedure for partitioning soil test correlation data into two classes. Soil Sci. Soc. Am. Proc. 35:658-660.

Christians, N.E., D.P. Martin, and K.J. Karnok. 1981. The interrelationship among nutrient elements applied to calcareous sand greens. Agron. J. 73:929-933.

Christians, N.E., D.P. Martin, and J.F. Wilkinson. 1979. Nitrogen, phosphorus, and potassium effects on quality and growth of Kentucky bluegrass and creeping bentgrass. Agron. J. 71:564-567.

Colclough, T., and P.M. Canaway. 1989. Fertilizer nutrition of sand golf greens III. Botanical composition and ground cover. J. Sports Turf Res. Inst. 65:55-63.

Colclough, T., and D.M. Lawson. 1989. Fertilizer nutrition of sand golf greens V. Rootzone nutrient analysis. J. Sports Turf Res. Inst. 65:73-79.

Dest, W.M., and D.W. Allinson. 1981. Influence of nitrogen and phosphorus fertilization on the growth and development of Poa annua (annual bluegrass). p. 352-332. In R.W. Sheard (ed.) Proc. 4th Int. Turfgrass Res. Conf., Guelph, ON, Canada. 19-23 July 1981. Ontario Agric. College, Univ. of Guelph, and Intl. Turfgrass Soc. Guelph, ON, Canada.

Dest, W.M., and K. Guillard. 1987. Nitrogen and phosphorus nutritional influence on bentgrass-annual bluegrass community composition. J. Am. Soc. Hortic. Sci. 112:769-773.

Fletcher, S.J. 1975. Soil survey of Sussex county, New Jersey. USDA SCS in cooperation with New Jersey Agric. Exp. Stn. and Cook College, Rutgers Univ., New Brunswick, NJ.

Fry, J.D., M.A. Harivandi, and D.D. Minner. 1989. Creeping bentgrass response to $\mathrm{P}$ and $\mathrm{K}$ on a sand medium. HortScience 24:623-624

Goss, R.L., S.E. Brauen, and S.P. Orton. 1975. The effects of N, P, $\mathrm{K}$ and S on Poa annua L. in bentgrass putting green turf. J. Sports Turf Res. Inst. 51:74-82.

Hesse, P.R. 1971. A textbook of soil chemical analysis. Chemical Publ. Co., New York.

Holt, E.C., and R.L. Davis. 1948. Differential responses of Arlington and Norbeck bentgrasses to kinds and rates of fertilizers. Agron. J. 40:282-284

Jones, J.R., Jr. 1980. Turf analysis. Golf Course Manage. 48(1):29-32.

Kuo, S. 1993a. Calcium and phosphorus influence creeping bentgrass and annual bluegrass growth in acidic soils. HortScience 28:713716

Kuo, S. 1993b. Effect of lime and phosphate on the growth of annual bluegrass and creeping bentgrass in two acid soils. Soil Sci. 156: 94-100.

Kuo, S., S.E. Brauen, and E.J. Jellum. 1992. The effects of aluminum and phosphate on the growth of annual bluegrass and bentgrass in some acidic western Washington soils. Soil Sci. 153:365-372.

Lodge, T.A., and S.W. Baker. 1991. The construction, irrigation and fertiliser nutrition of golf greens. II. Playing quality during the first year of differential irrigation and nutrition treatments. J. Sports Turf Res. Inst. 67:44-52.

Lodge, T.A., S.W. Baker, P.M. Canaway, and D.M. Lawson. 1991. The construction, irrigation and fertiliser nutrition of golf greens. I. Botanical and reflectance assessments after establishment and during the first year of differential irrigation and nutrition treatments. J. Sports Turf Res. Inst. 67:32-43.

Lodge, T.A., T.W. Colclough, and P.M. Canaway. 1990. Fertiliser nutrition of sand golf greens. VI. Cover and botanical composition. J. Sports Turf Res. Inst. 66:89-99.

Lodge, T.A., and D.M. Lawson. 1990. Fertiliser nutrition of sand golf greens. VII. Rootzone chemical composition. J. Sports Turf Res. Inst. 66:100-108

Magdoff, F.R., C. Hryshko, W.E. Jokela, R.P. Durieux, and Y. Bu. 1999. Comparison of phosphorus soil test extractants for plant availability and environmental assessment. Soil Sci. Soc. Am. J. 63:999-1006.

McIntosh, J.J. 1969. Bray and Morgan soil extractants modified for testing acid soils from different parent materials. Agron. J. 61:259-265.

Mehlich, A. 1953. Determination of P, K, Na, Ca, Mg, and $\mathrm{NH}_{4}$. Soil Test Div., Mimeo. North Carolina Dep. Agric., Raleigh, NC.

Nelson, L.A., and R.L. Anderson. 1977. Partitioning of soil test-Crop response probability. p. 19-37. In T.R. Peck et al. (ed.) Soil testing: Correlating and interpreting the analytical results. ASA Spec. Publ. 29. ASA, CSSA, and SSSA, Madison, WI.

SAS Institute. 1990. SAS/STAT user's guide. Vol. 1 \& 2. Version 6. 4th ed. SAS Inst., Cary, NC.

Sprague, H.B. 1933. Root development of perennial grasses and its relation to soil conditions. Soil Sci. 36:189-209.

Steckel, J.E., and R.L. Flannery. 1971. Simultaneous determinations of phosphorus, potassium, calcium, and magnesium in wet digestion solution of plant tissue by autoanalyzer. p. 83-96. In L.M. Walsh (ed.) Instrumental methods for analysis of soils and plant tissue. SSSA, Madison, WI.

Waddington, D.V., T.R. Turner, J.M. Duich, and E.L. Moberg. 1978. Effect of fertilization on Penncross creeping bentgrass. Agron. J. 70:713-718.

Wolf, A., and D. Beegle. 1995. Recommended soil tests for macronutrients: Phosphorus, potassium, calcium, and magnesium. p. 30-38. In Recommended soil testing procedures for the northeastern United States. 2nd ed. Northeastern regional pub. No. 493. Univ. Delaware Agric. Exp. Stn., Newark, DE. 